Drew M. Dalton*

\title{
Towards an Object-Oriented Ethics: Schopenhauer, Spinoza, and the Physics of Objective Evil
}

https://doi.org/10.1515/opphil-2018-0006

Received May 25, 2018; accepted August 1, 2018

\begin{abstract}
Objects are inert, passive, devoid of will, and as such bear no intrinsic value or moral worth. This claim is supported by the argument that to be considered a moral agent one must have a conscious will and be sufficiently free to act in accordance with that will. Since material objects, it is assumed, have no active will nor freedom, they should not be considered moral agents nor bearers of intrinsic ethical vale. Thus, the apparent "moral neutrality" of objects rests upon a kind of subject/object or mind/body dualism. The aim of this paper is to explore two paths by which western thought can escape this dualism, re-valuate the alleged "moral neutrality" of material objects, and initiate a sort of "object oriented ethics," albeit with surprising results. To do so, this paper explores the work of Arthur Schopenhauer and Baruch Spinoza to interrogate both the claim that material objects have no will and that freedom is the necessary condition for ethical responsibility. This paper concludes by arguing that not only should objects been seen as bearers of their own ethical value, a determinate judgement can be made regarding that value through a basic understanding of the laws of physics.
\end{abstract}

Keywords: object; ethics; evil; freedom; will; Schopenhauer; Spinoza; physics; thermodynamics; entropy

\section{On the alleged passivity and ethical neutrality of objects}

Objects are inert and passive - they are devoid of life and will; or, at least, so we have been told. This seemingly uncontroversial assertion has been maintained by the vast majority of metaphysical and ethical systems of the west. As inert and passive, material objects have traditionally been posited as morally neutral, bearing no intrinsic worth, inherent value, or ethical power outside of their use by or the judgement of some potent and active, living and willing force. ${ }^{1}$ The moral value of material objects, it thus follows, has been seen as purely accidental - derived entirely from its relation to some subject, whether human or divine; for, it has been thought, it is the subject alone who is the ultimate source of ethical concern and moral value. Ethical potency, from this perspective, appears to be an inexorably subject-oriented quality. This much is generally agreed upon. This general agreement, however, rests on a form of metaphysical dualism that is not nearly as uncontroversial. When this dualism is pressed, the whole edifice supporting the so-called ethical neutrality of objects collapses, and with surprising and horrifying results.

1 One possible exception to the pervasiveness of this assumption in the western philosophical tradition is some versions of "natural law theory," like that of Thomas Aquinas, where all natural material objects, as an extension of being or God, are endowed with the same inherent goodness of being or God itself. I will address this exception later. This is of course still a version of a subject-oriented ethics, with the ultimate subject being the personhood of God. And, even where such natural law theories are stripped of their theological assumptions, another ungrounded assumption troubles them: namely, that being must necessarily be good. This is an assumption which we will interrogate towards the end of this paper.

*Corresponding author: Drew M. Dalton, Dominican University, United States of America; E-mail: drew.dalton@hotmail.com 
The goal of this paper is to explore two places within the history of western philosophy where this dualism has been called into question, and to show how, through an understanding of those arguments, we may begin to re-valuate the ethical potency of material objects in their own right. In this way, this paper aims to ground what might be called an object-oriented approach to ethics, to borrow a phrase from Graham Harman. To accomplish these aims, the paper will survey the metaphysics and ethics Arthur Schopenhauer and Baruch Spinoza respectively, and show how together their versions of metaphysical monism could be used to reexamine the ethical quality of material objects. The paper will conclude by attempting to show how such a value could be determined through a basic understanding of the agreed upon nature of materiality as established by the laws of contemporary physics. Ultimately this paper will argue that not only should all material objects, indeed all matter in toto, be considered a moral force in its own right, it will argue that this moral force is, against our intuitions, not at all positive. In order to show how this could be the case, however, we must first lay bare the arguments underlying the generally accepted subject-oriented ethical systems which have dominated western thinking.

\section{The history and underlying assumptions of subject-oriented ethics}

The alleged ethical neutrality of objects is epitomized neatly in Shakespeare's famous phrase from Hamlet which declares that "there is nothing either good or bad, but thinking that makes it so." Of course, neither this sentiment nor this line is original to Shakespeare. It was in fact lifted, nearly word for word, from Michel to Montaigne's Essays, which Shakespeare drew heavily from both here and in the Tempest. ${ }^{3}$ Of course, Montaigne himself "borrowed" this phrase from Epictetus' Discourses and Enchiridion where it appears virtually identically. ${ }^{4}$ Epictetus, for his part, seems to take his wording from Seneca's Letters, where it is attributed to Socrates, who Plato, in turn, attributes it to Parmenides. ${ }^{5}$

Clearly, this is a sentiment which is widely shared, and not exclusively by the ancients or early moderns alone. Indeed, some version of this idea lurks behind Immanuel Kant's refusal to attribute moral worth to anything (or anyone, for that matter) who lacks the capacity to rationally and freely choose to express "goodwill." ${ }^{\prime}$ Another version of it supports Jeremy Bentham's argument for the instrumentalization of natural objects as a source of pleasure and/or pain by the moral subject; those objects having, he argues, no intrinsic worth outside of their utility to human happiness. ${ }^{7}$ Still another version of this claim underlies the sublime sophistry of Augustine and Aquinas's distinctions between natural evil (like sickness and disease) and what they consider to be true moral evil (like inordinate desire and malice). ${ }^{8} \mathrm{~A}$ similar distinction is also made by Rousseau and Voltaire, albeit without the theological overtones, in their debate over the level of moral culpability that could be assigned to various city planners, architects, and civic leaders following the devastation of the 1755 Lisbon earthquake, which killed nearly 100,000 people (over half of the city's population at the time), all while exonerating "nature itself" for its role in the carnage. ${ }^{9}$ More recently, Heidegger relied on a version of this claim in his account of the Zeugheit, or tool-being, of that which is "at-hand" (Zuhanden) for Dasein's use and concerns (Sorge).$^{10}$ The most ubiquitous expression of the alleged moral neutrality of objects assumed by the history of thought in the west is perhaps, however, the popular American slogan which states

\footnotetext{
2 Shakespeare, The Oxford Shakespeare: Hamlet.

3 De Montaigne, "That the taste of good and evil things depends in large part on the opinion we have of them," and "To philosophize is to learn how to die," in Michel de Montaigne: The Complete Essays. Most contemporary Shakespeare scholars agree that Gonzalo's speech in Act 2, scene 1 of the Tempest was inspired in no small part by Montaigne's "Of Cannibals.” See, for example: Go, “Montaigne's 'Cannibals' and 'The Tempest' Revisited.” Studies in Philology, 455-473.

4 See, for example: Epictetus, Discourses and Selected Writings, 112 \& 223.

5 See, for example: Seneca, The Stoic Philosophy of Seneca, 256

6 See, for example: Kant, Grounding for the Metaphysics of Morals, 393-397.

7 Bentham, An Introduction to the Principles of Morals and Legislation, 103 \& 209.

8 See, for example: Augustine, On Free Choice of the Will, 92-108; and, Aquinas, Aquinas's Shorter Summa, 125-133.

9 See, for example, Voltaire, “The Lisbon Earthquake,” 560ff.; and, Rousseau, "Letter from J.J. Rousseau to M. de Voltaire,” 232-246.

10 Heidegger, Being and Time, 96-98.
} 
that "guns don't kill people, people kill people." The logic of this statement is clear: it is not the objective piece of metal that is the source of the moral problems associated with the gun-violence epidemic in the United States. It is instead the actions of the moral agent who uses that object inappropriately. Indeed, it is this assumption which explains, at least in part, why the so-called "gun debate" in the United States perpetually shifts from questions concerning the value and regulation of guns themselves to questions concerning the "mental health" and/or criminal background of gun purchasers and owners.

Whatever its form, the basic premise shared by all of these arguments is the same: the claim that objects, as purely material, are entirely passive and, if left to entirely to themselves, guided by nothing more than the blind mechanics of the universe. As such, the argument continues, they cannot be considered bearers of any moral agency or intent, nor therefore properly subject to ethical judgement. Any ethical dilemma such objects may become embroiled in must be ultimately attributed to whatever agent puts them in motion or uses them, an agent who is to some extent free from the deterministic laws of universe and thereby capable of making moral choices. Only such a "free agent" or "moral subject" is the proper bearer of ethical responsibility, the argument concludes. It follows from this that it is only active and free subjects alone that can be subject to normative judgements and ethical evaluation. Any material object implicated in a morally questionable action is nothing more than a passive instrument wielded by a moral force outside of and beyond itself. As such, it should not be seen as either good or bad, but merely neutral. It is the thinker, the user, the agent or subject alone who is the proper bearer of ethical potency.

This basic argument which permeates nearly all of the ethical and moral philosophies of the west, with very few exceptions, rests upon on two seemingly uncontroversial interdependent claims. Firstly, it relies on the claim that: 1) to be considered a moral agent one must have a conscious will. In other words, to be considered ethically responsible one must have the capacity to think, to choose, and to act according to one's best judgement. This is, of course, why we do not typically hold the same ethical standards for so-called "moral patients," children, animals, or those suffering from a mental illness, as we do for ourselves, the assumption being that their will is not sufficient to be considered the proper source of their own action. Secondly, and following from this, this argument relies on the claim that, 2) to be held morally responsible a conscious will must not only be able to think, to choose, and to act, it must be free to do so as it sees fit. No matter how developed an active conscious will may be, we think, if it is not sufficiently free to choose for itself, then it cannot be held fully responsible for its actions. Thus, if someone is compelled against one's will to act in a certain way, through coercion or force, for example, then he or she is not traditionally seen as fully responsible nor entirely morally culpable for his or her actions. It is these two interdependent claims concerning the nature of will and freedom respectively, which have established the traditionally viewed necessary and sufficient condition for ethical agency; namely, free will.

The claim that material objects have no inherent moral value nor ethical responsibility simply follows deductively from the fact that they're seen as neither free nor willing. 1) Lacking a conscious will, it is argued, they cannot be considered to have any inherent agency. As such, it follows, purely material objects should not be considered the source of their own activity and thus should be not be considered responsible for any activity they display, whether moral or mechanical. Instead, they must be seen, as Aristotle put it, as purely passive hyle, mere "things," which receive the action they display from some force which lies beyond them. Material objects are only ever acted upon, the argument goes. They are entirely passive in the activity and movement they display. Their movement originates, perhaps even ultimately, Aristotle claims, with something which can move itself by virtue of its own inner potency. It follows from this that any ethical value such purely material objects may appear to possess should more properly be attributed to whatever agency initiated, either immediately or ultimately, their motion. Secondly, 2) since a material object's activity must originate from outside of and beyond itself, coming either from its use by a moral agent or its participation in the blind causal chain detailed by the mechanical laws of physics, such objects cannot be considered sufficiently free to act otherwise than they do and must not, then, be held ethically responsible for whatever good or evil they are implicated in. At most they can be taken up as moral-patients, things to which we have a duty and responsibility, but not things which bear any responsibility in and for themselves. Fault not the rock which hits you in the head, we have been taught to think, but the hand that throws it; and, if no hand has thrown it, then perhaps fault the God who created it and established the laws which governed 
its trajectory. Indeed, it is from precisely such a chain of reasoning that the so-called "problem of evil" or "theodicy" arises in western theology.

These two sub-arguments, derived from those assumptions concerning the ground and condition of moral responsibility, are what have traditionally established what we have called the apparent moral neutrality of material objects maintained by the western traditions. The problem is that neither of these arguments confesses openly nor sufficiently supports the metaphysical assumptions which underlie them; namely, the belief that there is some kind of obvious, if not absolute, ontological break which separates those beings or kinds of movement which are posited as free and active, those displayed by moral agents and subjects like you and me, from the being and movement displayed by material objects in the world, the falling rock which hits you, the tectonic plates which destroy your city, or the virus which infects your lungs. The problem is this: the arguments and assumptions supporting the alleged "moral neutrality" of objects rests on what appears to be an unadmitted and unquestioned subject/object dualism. It was in fact in large part recognition of the prevalence of this assumption which prompted Arthur Schopenhauer to launch a wholesale attack on the history of western philosophy in his 1819 World and Will and Representation and again later in his 1836 essay "On the Will in Nature." There Schopenhauer attempted to expose, examine, and ultimately overturn this pervasive dualism, replacing it with a new form of metaphysical monism. For Schopenhauer, the problem was not only that this dualism had gone unadmitted, and thereby unquestioned and unexamined for so long, it was, much more importantly, that he did not think that it bore up under any real scrutiny and indeed easily collapsed under both the weight of rational analysis and empirical evidence alike. Schopenhauer made this point perhaps most clearly in his treatment of the work of Immanuel Kant who he saw as advancing further than any in the history of philosophy before him the critical work of questioning the assumptions of the past and creating a new rationally coherent system, but who, nevertheless, he thought, fell into the trap of an unexamined dualism.

\section{Nature as willing agent in Schopenhauer}

Schopenhauer began his essay "On the Will in Nature" with the attempt to correct what he took to be a minor oversight in the Kantian schema, an oversight which he attributed to Kant's unquestioned allegiance to the metaphysical dualism of the history of western philosophy. Schopenhauer's correction of this oversight, however, as will become immediately clear, not only results in a complete inversion of the Kantian system, it undermines almost entirely the basic dualism it assumes, upending in the process nearly all of metaphysical and ethical conclusions made by Kant, including, as we will see, the alleged passivity of material objects. In this way, Schopenhauer's critique of Kant provides the first step in our attempt to interrogate the alleged "moral neutrality" of objects.

For Schopenhauer, the core insight of the Kantian system lies in his assertion in the first critique that "cognition and matter (subject and object) exist only relative to one another and constitute appearance."11 For Kant, it is only through the inextricable entanglement of knower and known that reality exists for us. The power of this insight, Schopenhauer thinks, is that it breaks down the distinction between active conscious subjects and passive unconscious objects and, by doing so, opens a way by which both subject and object could be seen as a modality of one primal agency. Indeed, according to Schopenhauer, Kant's formulation of phenomenal reality implies that existence be conceived of as a co-mingling of agency and objecthood - the known object possessing some legacy of the knowing agent who constitutes it, and the knowing subject containing some element of the objecthood which it constitutes within itself as known. Hence Schopenhauer's conclusion towards the beginning of Book II of the first volume of the World as Will and Representation that nature must be conceived of as possessing some kind of elemental or natural agency. ${ }^{12}$ It is this insight which Schopenhauer thinks opens the door to the collapse of metaphysical dualism and the natural rise, by reason alone, of a new metaphysical monism. This is not, however, he points out, a position

11 Schopenhauer, "On the Will in Nature," 340.

12 Schopenhauer, The World as Will and Representation, vol. I, 97. 
that Kant himself takes. This is due he thinks to a fundamental error Kant makes in the origin and root of agency, an error which, he thinks, rests on Kant's unconfessed, if not unaware, allegiance to subjectivity as an absolute category.

Where Kant errs in his understanding of the root of this natural agency, Schopenhauer claims, is his identification of it as "absolutely [...] the subject of metaphysics" a sphere which, Kant insists, is situated entirely within the intellect of the knowing subject - a product of the synthesis of the subject's structures of understanding. ${ }^{13}$ What such an identification assumes, Schopenhauer suggests, is that any elemental or natural agency attributable to the objective world must be conceived of as ultimately conditioned by and arising within the nature of an active knowing subject. This, for Schopenhauer, is the root of what he takes to be the Kantian error which he aims to "correct." 14

Schopenhauer reasons it thusly, if the knowing subject is the sole source of agency in the natural world, from whence does it derive this power; that is, its ability to know? We cannot, he thinks, attribute this power to the subject itself; for, to do so would be to abandon the principle of sufficient reason, a principle both Kant and Schopenhauer maintain vigorously in order to eliminate the kind of deus ex machina mysticism critical philosophy stands against. ${ }^{15}$ Schopenhauer thus concludes that the subject's agency must come from something within it which also stands beyond itself. But, he cautions, we must be careful in re-asserting the principle of sufficient reason not to situate the ground of the subject's agency in a greater or more powerful conscious life lest we reassert some form of dogmatic theology or theological first principle. To avoid this and remain true to the goal of Kant's critique, Schopenhauer thus suggests locating the source of the subject's agency within the noumenal realm itself; indeed, to make the thingin-itself a form of transcendental agency - an agency without subjectivity. ${ }^{16}$ To make this move, however, requires not only radically reconceiving of the primal nature Kant's noumenal realm, it requires collapsing the hard distinction Kant makes between the noumenal realm and phenomenal experience. So it is that on the way to this so-called minor correction of the Kantian conception of natural agency Schopenhauer, perhaps unintentionally, undermines the Kantian schema in toto asserting in its place a radical monism that grounds an entirely novel ethical system. Understanding how Schopenhauer accomplishes this is therefore essential if we are to see how his monism could be of use to us in our attempt to reexamine the moral value of material objects.

In order to argue that subjective consciousness is not in fact the condition for the possibility of agency in the phenomenal realm, but, vice-versa (that subjective consciousness is grounded and conditioned by some form of more primal natural object-agency), Schopenhauer must: 1) first reconceive the nature of the thing-in-itself as an active agent; and, 2) heal the divorce erected by Kant between the phenomenal and noumenal reality such that the two become contiguously related to one another, the latter operating as the ground and condition for the former. These assertions, he thinks, not only allow the phenomenal realm to be reconceived of as a conscious expression of the primal agency of the thing-in-itself, it further allows for the thing-in-itself to both be known in every intentional act of the conscious subject as well as experienced in every known object in the world. Clearly this is no minor correction nor expansion of the Kantian schema at all. It is an outright revolution of the Kantian critique, and the foundation to a kind of new speculative and empirical metaphysics.

To effect this speculative revolution, Schopenhauer begins by naming the noumenal thing-in-itself, as is well known: will. "[T]he core and principal point of my theory, its metaphysics proper" Schopenhauer writes, "[is] that paradoxical fundamental truth, the truth that what Kant called the thing-in-itself as opposed to mere appearance (more definitively called representation by me), and considered absolutely unknowable [...] is nothing other than that with which we are immediately acquainted and precisely intimate, that which we find in our innermost selves as will."17 This will is, for Schopenhauer, "the only

13 Schopenhauer, "On the Will in Nature," 325.

14 See, for example: Schopenhauer, The World and Will and Representation, vol. 1, 421.

15 Cf. Kant, The Critique of Pure Reason, 311.

16 Schopenhauer, The World and Will and Representation, vol. 1, 421.

17 Schopenhauer, “On the Will in Nature," 324. 
thing-in-itself, the only truly real thing, the only original and metaphysical thing;" and, what's more, this will "give[s] to everything, whatever it may be, the power by means of which it can exist and have effect," such that "not only the voluntary actions of animal beings, but also the organic drives of their living bodies, even the form and nature of their bodies, and further the vegetative growth of plants, and finally even in the inorganic realm crystallization and any original force anywhere that manifests itself in physical and chemical appearances - indeed gravity itself," all become ultimately the expression of, mere representations of, this primal will. ${ }^{18}$ "Matter," Schopenhauer writes, and the laws which govern it are indeed nothing more than "the mere visibility of the will." ${ }^{19}$ As such, he thinks, both material objects and the natural laws which govern them must been seen as expressions of the same primal agency which we experience as consciousness, as the will-to-know and desire. Indeed, according to Schopenhauer, the same will we experience within ourselves "is to be attributed to the inanimate, the inorganic." ${ }^{20}$ Material objects should not then be viewed as entirely separate and distinct from us, he argues, nor should they be treated as purely passive hyle or things, exclusively acted upon by some subjective agency which lies outside of and beyond them. To the contrary, he asserts, both material objects and knowing subjects alike must be seen as contiguously related - varying modes or expressions of a more primal activity and agency. So it is that for Schopenhauer, matter and subjectivity both become the embodied manifestation in which the inherent and natural activity of the universe as a whole shows itself. Both, he thinks, grow from the same noumenal ground. Indeed, Schopenhauer concludes, that all that is, knower and known alike, is an expression of the noumenal thing-in-itself figured as a primal will and dynamic agency.

In this way, Schopenhauer's critique of Kant not only overcomes subject/object dualism, it further also provides an intriguing means by which we can rethink the alleged "moral neutrality" of material objects. For if, as Schopenhauer claims, material objects and the laws they obey are the expression of a primal will, then they must be deemed to be active agents, containing within themselves the principles of their own movement. It is the will of the universe, Schopenhauer thinks, that a rock falls the way does, that the earth's mantle shifts beneath our cities undermining their stability, and that viruses replicate themselves in the way they do within our living cells. Such activity, however, must not be projected beyond them to some first mover. Instead, it should be attributed to the object which exhibits it alone, Schopenhauer argues, as the embodied object expression of the primal will of the universe: a will which we endeavor to map and chart through our empirical observation of these objects and which we represent in abstracted form as the mechanical laws of physics. This will is learned through the activity of material objects, which is theirs alone. Schopenhauer's assertion of the non-subjective agency of objects as actors with their own inborn will and determinate aim and objective, allows us to think of them as potentially the bearer of moral responsibility. In this way, Schopenhauer's monism provides a means for overcoming the first of the underlying arguments used to deny the potential moral culpability of objects. We cannot conclude from this yet, however, that such object-agents must necessarily be deemed moral agents, for their activity is not, he argues, free. Thus, while Schopenhauer's monism provides a means of thinking of the objects of the universe as active agents, he does not yet provide a means for thinking of them as necessarily moral ones.

Indeed, according to Schopenhauer, "[t]he hesitation and reserve we see in [western philosophers]" to acknowledge the existence of a primal will in nature, "stems from the fact that they too are biased by the antiquated opinion that consciousness is the requirement and condition of will," and their fear that an attribution of some form of will to objects make them moral responsibility, and thus potentially indistinguishable from us. ${ }^{21}$ Their reluctance thus flows, he argues, from a kind of humanistic hubris. More concretely, he thinks, it is the result of a failure to distinguish "will from free choice and understand that the former can exist without the latter," in such a way that objects can be seen as willing without, however being conscious or, therefore free in any meaningful way. ${ }^{22}$ According to Schopenhauer, while all existent

18 Ibid., 324.

19 Ibid., 369.

20 Ibid., 392.

21 Ibid., 377.

22 Ibid., 341. 
objects, human and purely material alike, should be seen agents, their agency should only considered free "when it is illuminated by cognition, and when motives, representations, are therefore the cause that move it." ${ }^{23}$ Thus while the rock, the earth, and the virus may display agency in their movement, unconscious and bound as they are by the will of the universe represented by the laws of physics, their activity should not be considered free, nor therefore be held morally culpable. Only through consciousness, he argues, do material objects have the potential of freeing themselves from the deterministic will of nature. Only in as much as they display active consciousness then, he concludes, should we consider agents to be ethically responsible. Therefore, according to Schopenhauer, only a conscious expression of the will, like a human subject's, should be considered ultimately a moral agent. ${ }^{24}$

In this regard, while Schopenhauer's work is useful to unsettle the first of the two claims we've set out to upend, his work only further entrenches us in the second. For Schopenhauer, "freedom and responsibility [are the] two fundamental pillars of all ethics."” "Responsibility," he thus concludes, "has freedom as its condition," and this freedom is for him the work alone of consciousness. ${ }^{26}$ Thus, while we may use Schopenhauer's work to think of material objects as willing and active agents, we cannot rely on it to attribute any moral or ethical responsibility to that agency. In this regard, Schopenhauer's work appears to ultimately collapse back into precisely the kind of subject-oriented ethics both he, and we through him, sought to escape. In order to make the further step towards granting objects their own moral value and worth, we must therefore go beyond Schopenhauer and pursue an even more radical monism.

It is worth noting, however, that the logic of Schopenhauer's critique of Kant's inconsistency in applying the law of sufficient reason could be used against him on this point. For, by denying material object ethical responsibility, regardless of their lack of freedom or consciousness, Schopenhauer appears to betray the logic of his own argument in much the same way he accuses Kant of doing. Note that if we grant to the knowing subject a power (in this case the ability to evaluate, judge, and bear responsibility) which separates it absolutely from the nature from which it springs, we can only do so by betraying again, only now in a new way, the same principle of sufficient reason Schopenhauer's correction of Kant sought to maintain. It is only by betraying this same principle that Schopenhauer is able to attribute to consciousness a power not found in other sorts of objects, a betrayal which results in his collapse back into a sort of subject-oriented ethics, despite all the work he did to escape precisely such subject/object distinctions in the formation of his metaphysics. It would make more sense, given the nature of that metaphysics, and following the logic of his critique of Kant, to simply attribute the subject's capacity to exercise ethical judgement and bear moral responsibility to the primal will of nature itself, rather than establishing it on the ground of consciousness and freedom. Such a move would allow us to attribute ethical responsibility to all natural objects, whether conscious or unconscious, and to avoid the apparent contradictions introduced by upholding the idea of freedom. This is, however, as we've seen, a move which Schopenhauer is for some reason reluctant to make. This reluctancy, perhaps ironically, mirrors precisely the reluctancy he mocks in his predecessors for their refusal to grant agency to the material world. If we, following the logic of his own minor correction of Kant, were to make a minor correction of Schopenhauer's own argument, we could easily discover a way of granting not just agency, but moral responsibility as well to all material objects. To do so, however, would require breaking with an orthodox fidelity to Schopenhauer's work as well as jettisoning the traditionally held idea that freedom is a condition for the possibility of ethical responsibility. In order to make the next step in our journey towards establishing an object-oriented ethics then we must move beyond Schopenhauer

\section{Ibid.}

24 We should note here that Schopenhauer viewed consciousness, and thus freedom and moral responsibility with it, as existing on the same monistic continuum that connects human subjects with material objects. Indeed, it was on this basis that he mounted a novel, and one of the first in the west, arguments for the ethical treatment of animals. As bearers of a less developed version of our own consciousness, Schopenhauer argues, animals must been seen as worthy of ethical consideration and even, in certain cases, ethical duty (such as the duty of the guard dog to its master). Nevertheless, Schopenhauer is not connived that animals are sufficiently free of their nature to deserve moral praise or blame. The guard dogs "duty" is for it only in keeping with its biological and natural imperative, qua representation of will.

25 Schopenhauer, “On the Will in Nature," 442.

26 Ibid., 443. 
by examining the work of someone whose break with the prevailing dualism of western metaphysics was not held back by the concept of freedom, someone from whom, in fact, Schopenhauer drew deeply: Baruch Spinoza.

\section{On the compatibility of determinism and moral responsibility in Spinoza}

The fundamental claim of Spinoza's monistic metaphysics and ethics is of course summed up neatly in the oft-quoted phrase, "Deus sive Natura," - a phrase which evokes for him the perfect unity of God as the primal cause of all that is, and the mechanical necessity of nature acting in accordance with the laws of physics. ${ }^{27}$ This perfect monistic unity which underlies the whole of Spinoza's system implies that everything which is, material objects and conscious subjects alike, exists both necessarily and interdependently with every other existent thing such that no single thing can be separated absolutely from any other thing. ${ }^{28}$ The knowing and willing human subject is thus for Spinoza ultimately no different in kind from the material world it knows, nor should its existence be seen as independent from the laws which govern the material world. There is instead a perfect continuity and unity between the kind of thing that we are, qua subjects, and the kind of thing that the rock, the tectonic plate, and the virus are. All are equal and indispensable expressions of the being of God both in and as the natural universe. The human subject is thus for Spinoza, nothing more than a single modality in which the conatus, or striving will or desire, of the whole of nature manifests itself. ${ }^{29}$ Thus, argues Spinoza, where the conatus of nature expresses itself in the law of gravity, as the governing principle of the motion and relation of material objects, that same will of nature, as the expression of God, manifests itself in the consciousness and desire to know of human subjects. It is in fact this argument, that the activity of the human mind is no different in kind than the motion of physical bodies, which is the lynch-pen of his argument against the prevailing dualism of western thinking. This argument allows Spinoza to see, alternatively, every physical object or body as a kind of mental activity or expression of subjectivity; and, conversely, every subjective activity, like human consciousness, as a kind of objective materiality. To make this clear, in section II, proposition 11, when addressing the nature of human subjectivity, Spinoza defines the mind as "part of the infinite intellect of God," or nature. ${ }^{30}$ As such, it is perfectly identified by Spinoza with a material body. Mind is, for Spinoza, nothing more than the idea of God in material nature. On the other hand, he goes on to argue almost immediately, every material object is equally endowed with this idea. Hence his claim in the scholium of proposition 13 that:

the things we have shown so far are completely general and do not pertain more to man than to other individuals, all of which, though in different degrees, are nonetheless animate. For of each thing there is necessarily an idea in God, of which God is the cause in the same way as he is of the idea of the human body. And so, whatever we have said of the idea of the human body must also be said of the idea of any thing. ${ }^{31}$

For Spinoza, the animation of any body, whether the star's flight through space according to the laws of physics or the human's cognition according to the laws of reason, is the expression of the nature of God in and as material reality - each operating according to the laws which govern its own nature. There is thus no absolute separation in kind or ontological distinction for Spinoza between the human subject and material objects. Instead, both are for him different manifestations of the same metaphysical oneness that is the being of God qua nature. In this way, Spinoza's monism, like Schopenhauer's, empowers us to think of objects as having a kind of inherent agency and will no different than our own. Where it differs from Schopenhauer

27 Spinoza, The Ethics in A Spinoza Reader: The Ethics and Other Works, 4Pref., 198.

28 Ibid., 1P14-16, 93-97.

29 Ibid., 2P9-12, 120-123.

30 Ibid., 2P11Cor., 123.

31 Ibid., 2P13Sch., 124. 
is that Spinoza's monism does not collapse before the question of freedom. Instead, it attempts to ground ethical responsibility on a more primal nature which allows it, as we will see, to be attributed to both human subjects and purely material objects alike. In this regard, a complete understanding of Spinoza's conception of both freedom and the possibility of moral responsibility is essential to the progress of our argument.

Since, for Spinoza, conscious life can in some sense be granted to all material objects, or vice-versa, material nature extended even into the conscious life of human subjects - the same laws which apply to each much apply to both. Just as the human subject can be said to act consciously and rationally, so to must the movement and actions of material object. From the trajectory of the thrown rock to the trembling of the tectonic plate and the replication of the virus, all activity is an expression of divine consciousness and will for Spinoza. Therefore, conversely, just as the material objects obey absolutely the laws of physics, so too do the mental activities of the subject operate in perfect accord with the mechanistic principles of the universe. The problem is, of course, as Spinoza details in sections IV and V of the Ethics, that the particular modality of nature manifest in the human, as conscious will, allows the subject to mistakenly think itself unique, separate, distinct, and independent from the laws which govern nature in its material modes, and therefore to think of itself as somehow free from the physical laws of the universe. ${ }^{32}$ This, thinks Spinoza, is the source of our natural tendency towards dualism; and, I'm sure he'd agree, was ultimately the cause of Schopenhauer's strange reluctance to grant ethical agency to objects. Nevertheless, Spinoza insists, "men are mistaken in thinking themselves free" in this way. ${ }^{33}$ Indeed, he writes "[t]his opinion consists in this alone: that they are conscious of their actions and ignorant of the causes whereby they are determined." ${ }^{34}$ Thus, the apparent freedom of subjective and conscious will is, Spinoza concludes, simply an error, a product of pure imagination. ${ }^{35}$

Were human consciousness able to transcend the limitations of the first person perspective and, via pure logic, ascend to the perspective of the whole, precisely what Spinoza's hopes his reader will achieve through the geometric method of argumentation he employs in the Ethics, they should be able to determine that, as he writes, "there is [in fact] no mind absolute or free will, but [instead] the mind is determined to will this or that by a cause which is determined by another cause, and this one again by another, and so on ad infinitum." ${ }^{36}$ Just as the rock is determined in its flight by the laws of physics, the mantle's trembling is determined by the principles of geo-thermal cooling, and the virus is determined in its replication throughout living cells by its genetic code, so too is human cognition and consciousness entirely determined by the laws of nature. As such, Spinoza concludes, human agency, as a conscious and willing expression of nature, is entirely bound and determined by the same mechanistic laws of physics observable in and representative of the conatus of material objects in the universe. The subject's relationship to the material world around it, experienced as the will-to-know, is thus for him ultimately no different in kind than the gravitational relationship established between the celestial bodies. The same primal will or conatus which set those celestial bodies in motion and maintains them along their course, is for Spinoza the same primal will that sets the human mind alight and inspires its imagination and wonder. According to Spinoza then, every conscious subject is just as determined, and even theoretically predictable in its metal activity according to the logic of the divine as every object is in its physical movement according to the laws of physics - each equally obeying its own modal expression of the conatus of God/nature, each falling, as it were, along its own pre-established course to its own inevitable end. "In nature," Spinoza concludes, "there is nothing contingent, but all things have been determined from the necessity of the divine nature to exist and produce an effect in a certain way." ${ }^{37}$ So it is that through a more radical metaphysical monism than Schopenhauer's, Spinoza does away not only with the dualism dominating western thought, allowing

\footnotetext{
32 Ibid., 3P9, 160.

33 Ibid., 2P35Sch., 137-138.

34 Ibid., 2P35Sch., 137-138.

35 Ibid., 2P44, 143-144.

36 Ibid., 2P48, 146-147.

37 Ibid., 1P29, 104-105.
} 
us to endow objects with the same activity and agency as the human, he does away with the concept of free will, upon which the traditional notion of ethical responsibility rested, entirely.

Nevertheless, and this is absolutely essential to our argument, Spinoza assures his readers that this lack of freedom in the human subject does not eradicate the ethical responsibility of nature. To the contrary, he insists, it is precisely the causal and mechanistic determinism of the system of nature which ultimately grounds its ethical responsibility and indeed, as we will see, extends its ethical power beyond the human to the whole of nature. To consider how this could be the case, of course, requires radically reconceiving the nature of ethics, and through it, the concepts of good and evil as well. This is, after all, the real aim of Spinoza's Ethics: to redefine the nature of ethical judgement and action in light of the kind of mechanistic determinism he thinks is required by a non-dualistic metaphysics. It is to this aim that the last two sections (IV and V) of his Ethics are dedicated.

There Spinoza begins by defining good and evil as principally categories of human understanding, goodness indicating for him a mode of conscious understanding which recognizes, acknowledges, and affirms the deterministic conatus or will of nature; and evil, in turn, indicating a mode of understanding which is ignorant of, refuses to accept, or attempts, however futilely, to resist the determining conatus or will of nature. Thus, "by good," Spinoza writes, "I understand that which we certainly know to be useful to us," that which, in other words, helps us to transcend our individual perspectives and know ourselves in light of the whole. ${ }^{38}$ And, "by evil," Spinoza writes "I understand that which we certainly know will prevent us from partaking of any good," i.e. that which further entrenches us within the limited perspectives of our individual wills or induces us to cling to the illusion of our freedom and individuality, thereby preventing us from thinking of ourselves in light of the whole. ${ }^{39}$ In light of these definitions, Spinoza envisions ethical responsibility as a moral duty each individual has to proceed, via logic and rationality, to the transcendental perspective whereby one may not only recognize oneself, and indeed every other existing being, as absolutely necessary, and necessarily the way it is, one can moreover affirm one's own will as perfectly in accord with the will of nature. Ethics is for Spinoza, in the words of Nietzsche, ultimately a form of positive amor fati - a means by which one may learn to love and affirm the fate which has made them the way they are. ${ }^{40}$ For these same reasons Spinoza has often been mistaken to be, like Nietzsche, a kind of relativist. After all, he does identify the concepts of good and evil as apparently little more than categories of a finite and limited human perspective on nature, a perspective which, he thinks, should eventually be sloughed off through a transcendental understanding of the whole, which is of course the aim of his Ethics. Spinoza's apparent relativism is further underscored by his claim that "we neither strive for, nor will, neither want, nor desire anything because we judge it to be good; on the contrary, we judge something to be good because we strive for it, will it, want it, and desire it," seemingly indicating that not only are the concepts of good and evil wholly human, finite, and limited, they are exclusively the product of human desire and not the reflection of any absolute nature..$^{41}$ Indeed, as Spinoza writes in the preface to section IV, "[a]s far as good and evil are concerned, they also indicate nothing positive in things, considered in themselves, nor are they anything other than modes of thinking, or notions we form because we compare things to one another." ${ }^{22}$ It is from statements like these which, proliferate section IV of the Ethics, that the casual reader concludes, quite naturally, the case on Spinoza's apparent relativism. For Spinoza, it would indeed seem at first glance that there is no case for any absolute value attributable inherently to the being of nature or the character of God and that, therefore, all ethical consideration be restricted exclusively to the realm of the finite and human. This is, however, far from the end of the story. To the contrary, as the careful reader will note, statements of this sort appear almost exclusively within sections III and IV of the Ethics, "Of the Affects," and "Of Human Bondage," respectively, where the everyday activity and understanding of human consciousness is laid

38 Ibid., 4Def.1, 200.

39 Ibid., 4Def.2, 200.

40 Nietzsche, “Ecce Homo," 714.

41 Spinoza, Ethics, 3P9Sch., 160.

42 Ibid., 4Pref., 199. 
out, diagnosed, and dismissed, the common conception of morality included. But, it is essential to note, as the title of section IV indicates, these ways of thinking are "bound." There is, however, a fifth section to the Ethics in which Spinoza explores what "freedom" from this bondage entails. If Spinoza were indeed truly a relativist one would naturally assume that concepts of ultimate value and ethical responsibility would not appear in this final section where Spinoza attempts to detail a mode of thinking which is not limited to the finitude of the human perspective, but which is in absolute and perfect accord with the irrefutable nature of the whole. And yet it is precisely there that Spinoza introduces what he calls the highest virtue.

According to Spinoza there, when one transcends the limited perspective of human understanding and everyday morality, in which reality is seen as contingent and existences are judged as separate and distinct and evaluated accordingly, as either good when conforming to ones desires, or evil when refusing them, and begins to understand the nature of existence as single, coherent, and whole, necessarily the way it is, one does not discover the universe devoid of value. To the contrary, he argues, by transcending the relative human values of good and evil, one discovers what he calls the highest or greatest virtue or value: knowledge of the true nature of the divine qua love. ${ }^{43}$ To achieve this greatest or highest virtue, Spinoza argues, one must understand him or her self, and indeed every part of the universe itself sub specie aeternitatis, that is as a "species of eternity," as a part of the eternal being of the divine. "Insofar as our mind knows itself and the body under a species of eternity," Spinoza writes, "it necessarily has knowledge of God, and knows that it is in God and is conceived through God." ${ }^{44}$ By acknowledging that we, and all that is, as well as all that has, can, and will happen to us, is part of the eternal and necessary being of God, Spinoza assures us, we can begin to affirm the universe as it is, and with it all that has happened within it, as the expression of God's existence. This allows us, he thinks, to begin to affirm the universe and all that has happened with joy.$^{45}$ Indeed, according to Spinoza, when we understand the universe in this way, we can begin to "take pleasure in [it], and our pleasure is accompanied by the idea of God as a cause." ${ }^{46}$ This is, for Spinoza, the definition of love, the absolute affirmation of the necessity of nature as an expression of the perfection of God's being..$^{47}$ And, it is through love of this sort, Spinoza concludes, that one lives a blessed life and passes into perfection. "If joy, then, consists in the passage to a greater perfection," he writes, "blessedness must surely consist in the fact that the mind is endowed with perfection itself." ${ }^{48}$ For Spinoza, by considering all things, even those things we judge to be entirely evil, sub specie aeternitatis, as part of the absolute necessity and perfection of the eternal being of God, we may ascend to the highest value and virtue of all: blessedness. It is to this highest virtue, Spinoza concludes there, that each of us must attend. "[T]he more each of us is able to achieve in this kind of knowledge, the more he is conscious of himself and of God, that is, the more perfect and blessed he is." 49 Hence freedom from the bondage of the concepts of good and evil is not for Spinoza the affirmation of a valueless universe nor the abandonment of ethical responsibility. To the contrary, it is for him the means by which we can achieve a higher understanding in which all things are judged in light of eternity - it is the achievement of a higher virtue and responsibility: perfection, blessedness, and love. It is with this claim that Spinoza concludes section V, and indeed the whole of his Ethics. It is not relativism, then, which has the last word for Spinoza, but virtue, a blessedness which is for him the affect of an understanding of eternity. In the demonstration and the scholium of proposition 42, the last proposition of the Ethics, Spinoza writes that one who has achieved the highest virtue of love or blessedness through knowledge of the eternal, "is hardly troubled in spirit, but being, by a certain eternal necessity, conscious of himself, and of God, and of things, [...] possesses true peace of mind." ${ }^{50}$

\footnotetext{
43 Ibid., 5P15, 253; and, 5P28Dem., 257.

44 Ibid., 5P30, 258.

45 Ibid., 5P27Dem., 257.

46 Ibid., 5P32, 259.

47 Ibid., 5P33Dem.\&Sch., 259.

48 Ibid., 5P33Sch., 259-260.

49 Ibid., 5P31Sch., 259.

50 Ibid., 5P42Dem., 263.
} 
It should be clear from this that Spinoza's dismissal of good and evil as relative terms, bound to the finite, is for him merely a way of transcending finite modes of human evaluation to attain what he deems to be the highest value: peace. Spinoza's alleged relativism is thus nothing more for him than the proverbial ladder which he uses to ascend through sections III and IV beyond the limitations of everyday morality to the heights of absolute virtue in section $\mathrm{V}$ whereupon this relativism is kicked out from under him. In this regard, it is improper to read Spinoza solely as a pre-cursor to Nietzsche, though he was of course influential on him. It is much more proper to read him as a novel inheritor of the kinds of natural theology espoused by Augustine, Maimonides, and Aquinas..$^{51}$ It is in light of the natural theological tradition then that we begin to understand Spinoza's conception of value, and indeed even good and evil, all the more.

It is only in light of eternity that Spinoza decries the apparent relativity good and evil as human concepts, bearing no absolute reality in and of themselves. He does, however, it should be noted in light of his final conclusions concerning the ultimate value of the universe, afford some privilege to the idea of good, all the while dismissing it as limited, something that is even hinted at in the preface to section IV. ${ }^{52}$ Since goodness is defined by Spinoza as that which wills along with the will of nature, and nature is perfectly identified with itself by definition (it cannot but will itself), nature can, in some sense then, Spinoza concludes, be considered good. This judgment is however, he argues, merely an understanding of nature sub specie durationis, that is, from the finite and limited perspective of a being in time. Nevertheless, it corresponds to the ultimate affirmation of the essence of nature sub specie aeternitatis achieved through the highest virtue, love, as an expression of transcendent understanding of the necessity of God. As such, while the concept of goodness is not for him an expression of any ultimate reality, Spinoza nevertheless thinks that it is an idea which is in keeping with the idea of ultimate perfection which can be achieved sub specie aeternitatis as blessedness. Evil, on the other hand, is understood by Spinoza as a form of "imperfection," sub specie durationis which results from the failure to see things properly in light of the necessity of being. Evil then is nothing really at all for Spinoza - little more than a kind of misunderstanding which exists exclusively sub specie durationis in limited human understanding. It therefore has no natural correlate sub specie aeternitatis and no eternal essence. The concept of evil is for him the result of thinking of nature as contingent and believing that it could somehow be otherwise than it is. It is the result, in other words, of failing to judge reality in light of eternity. It follows from this, in keeping with the tradition of natural theology, that for Spinoza while the concept of evil is truly nothing at all, a properly empty designator, the concept of goodness is, by contrast, while limited and incomplete by human understanding, nevertheless a reflection of some eternal reality: namely the absolute necessity of the being of God understood sub specie aeternitatis. The concept of goodness thus has some eternal essence for him as an expression, sub specie durationis, of the necessity of all things in God, a necessity which, once understood and affirmed sub specie aeternitatis, becomes the highest virtue. Goodness is for Spinoza, in other words, the finite expression of that absolute love which is the affect of eternity perceived, as it were, "as if through a glass darkly."

It should be clear from this that Spinoza's monism, while denying the possibility of free will, does not do away with the ethical value in toto. To the contrary, his metaphysical monism is a means of affirming a higher value and asserting it as a property of all of existence, subject and object alike. For Spinoza, as for the other natural theologians, the whole of existence is imbued with ethical value, and indeed responsibility. Though the human subject and material objects alike are thus not in any real sense free, both determined as they are by natural physical laws, Spinoza nevertheless asserts the ultimate value of all things as part of the being of God, sub specie aeternitatis. Moreover, he argues, all things are, as such, ultimately responsible to God and thus should equally pursue the highest virtue of affirming in love the absolute necessity of their being as well as all that happens to them, through them, and around them. For the rock, of course, this is easy as it cannot understand itself other than it is. Its activity is always in perfect union with the laws of the universe as the illusion of freedom is not for it an option. For the human, however, such fidelity

51 Indeed, Spinoza interacted significantly with Maimonides with whom he disagreed significantly all while maintaining a certain affinity, (see, for example: Spinoza, “Letter 43,” 871). For more on Spinoza's relation to Maimonides see: Parens, Maimonides and Spinoza: Their Conflicting Views on Human Nature.

52 Spinoza, Ethics, 4Pref., 197-200. 
and perfect obedience is significantly harder as its modality of the conatus, qua consciousness, allows it certain illusions, like freedom and contingency, and through them the possibility of believing itself separate from the world, able to act on its own against nature, or will itself to be otherwise than it is. Such a misunderstanding can be understood, thinks Spinoza, sub specie durationis, as the source of evil. However, as we have seen, since this is only ever a misunderstanding, since in reality the human, like every other material object, can only ever do what it has always been determined to do, it is never properly in rebellion from nature nor separate from the being of God. Thus, even amidst the perdition of its misunderstanding and confused attempts to wrest itself free, separate, and distinct from nature, Spinoza stills holds out hope for the possibility of blessedness and the highest virtue. But, in order to achieve this, however, he thinks each individual must be responsible to the absolute necessity of God qua nature, and responsible for its own obedience to this necessity by affirming nature as it is rather than futilely attempting to will otherwise. To achieve what Spinoza calls perfection, it is the duty of every individual to bring its singular will into perfect affirmation and accordance with the will of nature/God. Thus for Spinoza the eternal essence of goodness can only be achieved as perfection by the human individual by endeavoring to understand itself sub specie aeternitatis and make itself perfectly obedient to the will of the universe. In other words, the human can only achieve the highest virtue which is acts like every other material object in existence.

In this way, Spinoza's monism provides a means by which we can overcome the second of the claims we identified as underlying the argument for the so-called "moral neutrality," of material nature, that which asserts the necessity of freedom for moral responsibility. For Spinoza, ethical responsibility arises precisely in recognition of the fact that we are not free. Freedom, for him, is not the condition for ethical responsibility. To the contrary, the idea of freedom is precisely the rejection of ethical duty. For Spinoza, the real condition for the possibility of ethical responsibility is a recognition of the true nature of all things sub specie aeternitatis as part of the one being of God/nature. The highest expression of ethical responsibility, the highest virtue, in other words, comes for him through a recognition and affirmation of necessity when understood in light of eternity. In this way, Spinoza's metaphysics allows us to make the final move in our argument to consider material objects not merely as agents, as Schopenhauer encouraged us to do, but as agents which can indeed be held ethically responsible for their actions, so long as their actions are measured with a proper understanding of eternity.

\section{Natural theology and the problem with eternity}

The problem with Spinoza's version of natural law theory, and indeed natural law theory as a whole, is that while it at times appears to break with the assumptions which ground the alleged "moral neutrality" of objects, it does so only by asserting yet another ungrounded assumption: namely, the inherent goodness, virtue, or blessedness of nature. This is an assumption, however, which, can only be maintained, as Spinoza makes clear, if the natural trajectory of the universe, either by divine decree or fortunate accident, is to affirm itself eternally. It is only in light of eternity, the argument goes, that the suffering we endure in existence could potentially be redeemed. Indeed, as we saw, the heart of Spinoza's argument for the perfection and blessedness of existence hinged on understanding all that is, as well as all that has ever happened, sub specie aeternitatis. The potential goodness of material objects, whether it be the rock which strikes us, the earth which rumbles beneath us and destroys our cities, or the virus that infects our bodies and undermines our health, rests for Spinoza on the claim that all that is and everything which has happened is ultimately redeemable in eternity as an expression of the necessary being of God. Whatever apparent "evil" we suffer in time, sub specie durationis, Spinoza and his fellow classical natural theologians agree, can ultimately be justified as "good" when understood sub specie aeternitatis as part of the necessity of God. Thus, they argue, the wise person who understands the nature of God and attempts to affirm and love its necessity, can call even the worst atrocities and suffering, sub specie aeternitatis, a kind of blessedness. In this regard, it is not hard to imagine Spinoza affirming with the author of the book of Romans in the Christian New Testament that "for those who love God all things 
work together for good." ${ }^{33}$ In light of the eternity, even the most horrendous events of human history, both Spinoza and the natural theologians claim, become merely episodes in the eventual emergence of perfection - part of the story of God's love.

The blessedness of material objects and the effects on the universe thus hangs exclusively for natural law theorists like Spinoza on the claim that the universe is indeed eternally self-affirming - that the underlying will of the universe is indeed to maintain itself in perpetuity. The problem is, as we will see shortly, the eternity of existence is an enormous assumption to make; one moreover which is no longer justifiable in light of the discoveries of more contemporary physics. Thus, while Spinoza has every reason to argue that the universe maybe governed entirely by deterministic mechanical laws, laws which require that the universe and everything within it, you and me included, are not in fact free; but that nevertheless, we should hold the universe and everything within it, including you and me, the desk on which I write, the house in which I live, and indeed literally every other existing object, morally accountable as the expression of a natural will and agency, we cannot assume the benevolence of that will as a means to the highest virtue or an expression of ultimate blessedness unless it is the natural trajectory of the universe to sustain and uphold itself eternally. Remember, as Spinoza states, we can only affirm the necessity of the movement of material objects as an expression of love if such a movement can be measured and judged sub specie aeternitatis. It is only as a species of eternity that our temporal suffering can be redeemed as a means to the end of the highest virtue and ultimate blessedness. It is thus only as a species of eternity that the inherent value of the object agents of the universe can be affirmed as virtuous. What would become of this value, however, if it became apparent that it was not the will of the universe to endure eternally? What if, instead, it became apparent that it was the will of the universe to destroy itself through its materiality? What could be said of the value of material, objective existence then? What if, in fact, all that exists, every material object along with our own subjective existence, were viewed as precisely the means through which the universe manifested its will towards annihilation? What would become of the inherent value of material objects under such conditions? Would they simply disappear, collapsing into a valueless or morally neutral position once again? Or, is it possible that a much more menacing reality might appear, a kind of inverted natural law theory - one in which the existence of every material object becomes the embodied expression of a supererogatory malice? Is it possible that while the logic of Spinoza's argument for the ethical responsibility of material objects is correct, his conclusions concerning their value is wrong? Is it possible that objects are not in fact an expression of absolute love, but quite the opposite, a primal hate? The entirety of Spinoza's conclusions concerning the virtue of existence, subjective and objective alike, rests on his assumption of the eternal affirmation of the being of nature. This is, however, something which most contemporary physicists agree is easily refutable, and, as we shall see, with devastating ethical consequences.

\section{The laws of thermodynamics, evaluated}

For most contemporary physicists, the laws of thermodynamics define the basic principles by which every other physical law, including the classical laws of motion, are governed and determined. The first of these laws, also known as the law of the conservation of energy, states that energy, as motion, matter, or heat, can neither be created nor destroyed within a closed system; that, in other words, energy can only ever change states within a closed system. The second law of thermodynamics states that energy attempts to distribute itself evenly across every system. This distribution, known as entropy, means that every closed system aims, or wills as it were, towards a state of absolute energy equality, where no one thing possesses any more or less energy, in the form of motion, matter, or heat, than any other thing. It is this law which, physicists explain, ensures that time only moves in one direction - that, as Brian Greene puts it, a cup of coffee can spontaneously become cold as it distributes its energy to the room around it, but will never grow

53 Romans 8:28, ESV. 
spontaneously hot. ${ }^{54}$ It is this law, then, which gives direction to what is known as the irreversible "arrow of time" of the universe. It is also this law which ensures that all things, whether in the form of matter, motion, or heat, necessarily "fall apart," in the words of Yeats. Finally, the third law of thermodynamics states that, since entropy must necessarily increase in a closed system, the most evenly distributed state of energy possible within that system is a state in which every existent thing possess the absolute lowest total amount of energy possible, a state known as "absolute zero" - the ultimate expression of this state is, of course, a system in which there are no existent things, just a low level background radiation evenly distributed across the total system.

What all of this means, of course, is that it is the absolute and unavoidable trajectory of matter to disintegrate, to collapse, and to slouch inexorably towards nothingness. It is the will of the material universe, in other words, to slowly destroy itself and with it all existent objects, you and I included. Indeed, in light of these laws and the observations of astronomers that the universe appears to be expanding, the vast majority of contemporary astrophysicists agree that the ultimate fate of our universe is what is called "the Big Freeze" or "absolute heat-death" - a time in our distant future in which all material objects will have exhausted themselves and been irreparably annihilated by the underlying laws of the universe leaving nothing at all, merely an inconceivable infinitely expanding void. Interestingly, most contemporary astrophysicists think that these laws not only explain the eventual end of the universe, but its beginning as well - complex material objects emerging as an efficient way of ridding the universe of the surplus energy contained within the cosmic singularity which preceded the big-band/rapid expansion. In other words, the creation of the known universe, from the formation of simple elements and electrons, to the condensation of gasses, galaxies and stars, along with every other material object, is nothing more than the most efficient means through which the proto-cosmos could destroy itself.

More recently, bio-physicists have used this same logic of thermodynamic entropy to even explain the emergence and evolution of life itself, biological life being an especially efficient machine for the distribution of energy as it can convert matter into heat. This explanation of the emergence of complex life, dubbed by MIT physicist Jeremy England "dissipation driven adaptation," is a process which ultimately explains, he thinks, even the emergence of conscious life itself, now cast as nothing more than perhaps the most efficient means by which the universe can rid itself of energy and destroy itself. ${ }^{55}$ According to this logic, every material object, especially those more complex objects like living and thinking objects, is ultimately nothing more than a cog in a machine which aims to disassemble itself and all its parts.

From this it should be clear that it is not the will of the universe to affirm itself eternally, nor to uphold its own being infinitely. To the contrary, it is the fundamental trajectory of the universe to destroy itself and, along with itself, everything else in existence. This is the final and ultimate destiny of matter - this is the absolutely determined fate of all things. All material objects, ourselves included, are the agents of this obliteration, the efficient means through which the self-annihilating will of the universe accomplishes its aims. If we are to follow the argument we have pursued here to its logical end, we might conclude that all that is, all that has ever happened to us or will happen to us, every injury we have suffered, war we have waged, tragedy we have endured, or sickness we have faced was not an accidental episode in the story of eternal blessedness or love, nor an expression of a higher virtue which we have failed to understand properly, limited as we are by our own finitude. To the contrary, all this suffering, all of the hatred and destructions which marks human history, is essential to our existence. It is our very purpose. It follows from this that if we assign an inherent value to existence as a whole and all the material objects which compose it, it may not in fact be positive, nor even neutral. It may in fact be negative. It may in fact be, for lack of a better word, evil.

What this means, of course, in stark contrast to the prevailing opinions of western metaphysics, is that material objects may not in fact be "morally neutral," nor ethically passive. Neither, however, should we call material reality inherently good, an expression of an eternal virtue. To the contrary, if the universe and all that composes it, every single subject and object alike, is to be assigned a value, then it follows that, as

54 Greene, The Fabric of the Universe: Space, Time, and the Texture of Reality, $143 f f$.

55 England, "Dissipative Adaptation in Driven Self-Assembly," 919-923. 
the expression of a primal annihilating will, we consider the possibility that the primal value of the universe is pure and unmitigated evil. ${ }^{56}$ Nature itself, and through it every material existence, may in fact be the expression of a primal malevolence, regardless of how we think about it, use it, or act upon it.

It is possible, as we saw with Schopenhauer, to view material objects as agents acting in perfect accordance with the laws of nature which determine them. Nevertheless, as Spinoza argued, such objectagents must still be assigned an inherent value and held ethically responsible for their actions as agents of the absolute. This was a value which, as we saw, is determined for him, by their service in the absolute necessity of eternity. As agents of the eternal, material objects are for him manifestations of perfection. The problem is, as contemporary physicists have shown, it is not the will of the universe to endure eternally. To the contrary, it wills to annihilate itself. Indeed, every material object is an expression of and agent for this annihilation. If we are to follow the logic we have traced here, then we can only conclude that it is not a benevolent will which we see exhibited in the movement of material objects, it is an irreparably antagonistic one. It is the will of every material object to effect the destruction of itself and every other existent thing. To act in accordance and affirmation of this will is therefore to become an accomplice to the most horrifying atrocities imaginable. Material objects, as the perfect unbending agents of the annihilating will of the universe, bound as they are in perfect obedience to the mechanical laws of physics, are thus exposed as nothing less than foot soldiers of the inevitable apocalypse. What else can we conclude from this than the fact that material objects, as ethical agents, are not morally neutral, but instead absolutely devoid of goodness - utterly and completely morally reprehensible? If we follow the kind of inverted metaphysical and ethical monism we have explored here, we could conclude that if any goodness is to be sought in the universe, it could only appear as an illusory possibility held out exclusively to a conscious entity like the human who, in recognition that the will of the universe is malicious and, falsely believing itself potentially free from that will, could endeavor to resist annihilation and preserve existence, however impossibly, against the entropic march of time, though we must immediately acknowledge that such an illusory resistance would ultimately fail and come to nothing.

\section{Object oriented ethics; or, ontological pessimism}

My goal in this paper has been to initiate a kind of "object oriented ethics," borrowing and altering a phrase from Graham Harman..$^{57}$ The aim of Harman's "object-oriented-ontology," is of course to initiate an ontology which is not merely directed towards objects, but which is directed by the nature of objects - an ontology which is oriented around and takes its cues from the primal reality of the world around us. Harman's goal, as he writes is to "describe [...] how objects relate to their own visible and invisible qualities, to each other, and to our own minds - all in a single metaphysics." ${ }^{58}$ In this way, Harman, alongside his fellow "speculative realists," hopes to formulate a method by which phenomenology, and indeed metaphysics and ontology as a whole, can finally escape the limitations of the kinds of idealism, psychologism, or correlationism which see objects as nothing more than a projection of a subjective consciousness which, by virtue of its consciousness, is separated and cordoned off from the rest of nature..$^{59}$ Such an understanding, Harman rightly notes necessarily relies on a kind of "shoddy dualism" which separates "human thought on one side and everything else in the universe on the other." 60 Harman's aim is to break with dualisms of this sort and grant to objects an existence, and perhaps even

56 In this regard I'm interested in revitalizing a kind of profoundly secular version of Manichaeism, a twisted neo-Manichaeism as it were, which sees the entirety of material reality, including every object, as not only base and crass, but the very root of evil itself - indeed, its very ground, condition, cause, and effect.

57 See, for example: Harman, Tool-Being: Heidegger and the Metaphysics of Objects.

58 Harman, The Quadruple Object, 7.

59 See, for example: Bryant, Levi et. al. eds., The Speculative Turn: Continental Materialism and Realism; and: Sparrow, The End of Phenomenology: Metaphysics and the New Realism. Cf. Harman, Object-Oriented Ontology: A New Theory of Everything, 6. 60 Harman, Object-Oriented Ontology, 56. 
value, which is radically their own, emergent from, and supported by their own ground. ${ }^{61}$ As Harman states, object oriented ontology "is a bluntly realist philosophy [which] means among other things that [it] holds that the external world exists independently of human awareness." ${ }^{2}$ Indeed, this aim to maintain and defend the radical alterity and independence of objects, "[t]his withdrawal or withholding of things from direct access," as he calls it, "is the central principle of [object-oriented ontology]." 63 Hence the persistent reference throughout his work to Kant's concept of a thing-in-itself, a thing which exists absolutely cordoned off from human understanding, albeit with an entirely different emphasis. ${ }^{64}$ In this regard, Harman and I are perfectly in accord: the chief aim of this paper being to argue for the possibility of evaluating material objects independently of our use, interest, or existence.

Of course, how I have used the word object here may give Harman some pause, given the narrow, materialistic sense of a brute physical phenomenon I have pursued. In contrast, Harman famously wants to maintain as broad a definition of objects as possible. Indeed, according to Harman, object-oriented ontology uses the word object "in an unusually wide sense." ${ }^{\prime 5}$ For Harman, then, "an object is anything that cannot be entirely reduced either to the components of which it is made or to the effects that it has on other things," whether it be a physical material object, like the kind examined here, or a fictional immaterial object, or even an event or process. ${ }^{66}$ Note then, however, that while Harman and I use the word 'object' slightly differently, his definition does not exclude the use pursued by this paper. At worst, Harman might caution me against what he calls physicalism, which he defines as the false assumption that "everything that exists must be physical." 67 Indeed, it is against precisely such reductions that much of Harman's work focuses, as evidenced in his 2016 book Immaterialism where he argues forcefully against such reductionistic materialisms. ${ }^{68}$ Nevertheless, Harman's interest in immaterial objects has never denied the existence of purely material objects like the kind explored here. To the contrary, Harman states that "[f]or the object-oriented thinker, physical objects are just one kind of object among many." ${ }^{\circ 9}$ Thus while Harman may caution against the danger of a potentially eliminative or exclusory account of material objects alone, he certainly wouldn't oppose a rigorous account of material objects either, despite confessing he "has no interest whatsoever in the concept of 'matter' let alone materialism." ${ }^{70}$ Nevertheless, Harman writes, that there are "several different ways to view the meaning of [object oriented ontology]," as well as "an extremely broad method," of approaching it so long as each approach aims to "rescue the non-relational core of every object," which is certainly the aim of this paper. ${ }^{71}$

Where Harman and I differ more radically is in our metaphysics and in our understanding of the autonomy of objects. For Harman, one of the fundamental aims of object-oriented ontology is to "defend the idea that objects - whether real, fictional, natural, artificial, human or non-human - are mutually autonomous." 72 From this it should be clear that Harman sees the existence of objects as radically independent, not only of our perception and use, a point on which we agree, but also from one another and indeed even their own constitutive elements. Objects are, for him, "opaque," and "withdrawn" both from us, from one another, and even from themselves such that the "multiple parts," of which an object might be "composed jointly," do not for him necessarily interact. ${ }^{73}$ Harman's ontology is in this sense is radically pluralistic, composed as it is of a potentially infinite number of objects, and

61 Harman, The Quadruple Object, 19.

62 Harman, Object-Oriented Ontology, 10.

63 Ibid., 7.

64 See, for example: Ibid., 259.

65 Ibid., 43.

66 Ibid.

67 Ibid., 25.

68 Harman, Immaterialism: Objects and Social Theory, $13 \mathrm{ff}$.

69 Harman, Object-Oriented Ontology, 39, emphasis mine.

70 Ibid., 258.

71 Ibid., 255, 256.

72 Ibid., 12.

73 Ibid., 11, 12, 32, respectively. 
emphasizes thereby the freedom of all objects, primarily from us, but also from one another, and indeed even themselves. Indeed, in perhaps the most concise definition he gives of his aims Harman defines object oriented ontology as interested "in how things in the broadest possible sense of the term do not hang together in the broadest possible sense of the term, but maintain a degree of autonomy despite their interrelations." ${ }^{74}$ In stark contrast, the object-oriented ethics I have pursued here is most definitely monistic, seeing all material objects as emergent from or the expression, mode, or representation of a single primal underlying drive or will towards entropic annihilation. As such, I afford no real freedom, in any conventional or genuine sense of the term, to material objects, human or otherwise, but instead insist on the absolute necessity, and in many cases even determinism, of reality - the ineluctable march of all objects towards their own and mutual destruction. Given these profound differences it is clear that the object oriented approach to ethics pursued here cannot and should not be seen as completely harmonious with Harman's object-oriented ontology. Though we both attempt to overcome the idealistic dualisms of the past and to initiate an object-oriented account of reality which insists on the radical independence and alterity of objects from human perception and use, our metaphysical assumptions and approaches to this task diverge significantly. Nevertheless, I think the overlap of our aims is enough to justify my borrowing of the phrase. After all, as he openly admits, Harman himself "borrows the phrase 'object oriented' from the world of computers, rather than taking inspiration from the details of that world." 75 This is a sentence which could equally apply to my use of this phrase in this paper. While I'm interested in using the phrase 'object-oriented' popularized by Harman, the line of reasoning I've pursued here does not take any "inspiration from the details," of his work.

My aim in proposing the possibility of an "object oriented ethics," is to suggest that we needn't follow Shakespeare's adage that "there is nothing either good or bad, but thinking that makes it so," when considering the possible value of material objects; but, to the contrary, we must consider things to be good and/or bad in and of themselves, independent of our thinking. I agree then with Harman that to accomplish this requires overturning a number of the assumptions maintained by classical philosophy concerning the nature of objects, specifically their possible agency and moral responsibility. Where I break with Harman, however, is that I think that in order to accomplish this task we must first show how material objects can be seen to be the expression of a single primal natural will, something we pursued here through an exploration of Schopenhauer's monistic metaphysics. Following this I sought to show, how such a metaphysics, while rejecting the freedom of material objects, insisting as it does on their absolute obedience to the will of the universe detailed by the laws of physics, does not imply their moral neutrality. To the contrary, I have argued, through an exploration of Spinoza's ethics, how ethical responsibility could still emerge from a wholly deterministic monism. By following this with a quick survey of the current understanding of the universe maintained by contemporary physics I hoped to prove that if some inherent value were to be attributed to material objects, in contrast to nearly every position maintained in the history of western philosophy, then they must be judged as complete and total reprobates - the expression of an essential and primal maliciousness.

It is my contention that nature in itself and every material object in existence, human or otherwise, be evaluated as kind of primal or radical evil - "red," as Alfred Tennyson put it, "in tooth and claw," fundamentally, irrevocably, and entirely aimed towards murder, destruction, and, ultimately, annihilation. ${ }^{76}$ I see the kind of pessimistic ontology this argument relies on as a sort of inversion of classical natural law theory, an inversion which requires that we rethink the relation of good and evil and establish the latter as what is natural and the former as whatever breaks with it. Following from this, it is my hunch that if we were forge a theory of the good from this metaphysics, it would require us to think it negatively, defining it as that which endeavors to resist the trajectory of materiality, however futile such a resistance might be. The advancement of such a theory would of course take much more work and time than I have here; but it would

74 Ibid., 41.

75 Ibid., 11.

76 For more on how the ultimate trajectory of nature towards annihilation bears an ethical problem for philosophy which revitalizes the kind of ontological pessimism I've forwarded here, see: Brassier, Nihil Unbounded: Enlightenment and Extinction. 
seem that it is only in resistance to the absolute trajectory all material reality that some concept of the good could be maintained within the metaphysical system we've explored. ${ }^{77}$

To this, the careful reader may ask, how exactly could such a good be pursued? How is one to resist the fundamental laws of thermodynamics, the underlying laws of nature itself? Such a resistance is of course impossible. Even if such a project had a clear prescriptive course of action, nothing could be hoped to be achieved from its enterprise. There is no escape from our very physical nature, after all; and it is a fool's errand to attempt to resist the very laws of the universe which form us and determine our every move. All things must collapse and every action will eventually work together for the ill will of the universe. But, perhaps it is precisely the absurdity of activities of this sort which endeavor to unreasonably and impossibly resist or break with the trajectory of the universe which open the possibility of imagining them as good, falling outside, as they do, the implacable logic and reason of the laws of physics. After all, as Albert Camus concluded in his meditations on the absurdities of Sisyphus, "I cannot see what my revolt loses by being useless, and I can feel what it gains." ${ }^{\text {78 }}$ Perhaps it must be in pursuit of such intangible gains that a properly object-oriented understanding of the good qua resistance must aim. At the very least, it is a path away from the errors of the ethical systems of the past which have blithely maintained the alleged "moral neutrality" of material objects and, in doing so, have potentially made themselves accomplice to the horrors of natural history.

\section{References}

Augustine. On Free Choice of the Will, trans. Thomas Williams. Indianapolis: Hackett Publishing, 1993.

Aquinas, Thomas. Aquinas's Shorter Summa, trans. Cyril Vollert. Manchester: Sophia Institute Press, 2002.

Bentham, Jeremy. An Introduction to the Principles of Morals and Legislation. Mineola: Dover, 2007.

Brassier, Ray. Nihil Unbounded: Enlightenment and Extinction. New York: Palgrave MacMillan, 2007.

Bryant, Levi et. al. eds. The Speculative Turn: Continental Materialism and Realism. Melbourne: re.press, 2011.

Camus, Albert. Notebooks: 1935 - 1942, trans. Philip Thody. New York: The Modern Library, 1963.

Dalton, Drew. The Ethics of Resistance: Tyranny of the Absolute. London: Bloomsbury, 2018.

England, Jeremy. “Dissipative Adaptation in Driven Self-Assembly," Nature Nanotechnology, vol. 10, Nov. 2015: 919-923.

Epictetus, Discourses and Selected Writings, trans. and ed. by Robert Dobbin. London: Penguin Books, 2008.

Go, Kenji. “Montaigne's “Cannibals” and “The Tempest” Revisited.” Studies in Philology, vol. 109, no. 4, 2012. pp. 455-473.

Greene, Brian. The Fabric of the Universe: Space, Time, and the Texture of Reality. New York: Vintage, 2004.

Harman, Graham. Immaterialism: Object and Social Theory. Cambridge: Polity Press, 2016.

Harman, Graham. The Quadruple Object. Winchester: Zero Books, 2011.

Harman, Graham. Object-Oriented Ontology: A New Theory of Everything. London: Pelican Books, 2018.

Harman, Graham. Tool-Being: Heidegger and the Metaphysics of Objects. Chicago: Open Court, 2002.

Heidegger, Martin. Being and Time, trans. John Macquarrie and Edward Robinson. New York: Harper and Row, 1962.

Kant, Immanuel. The Critique of Pure Reason, trans. and ed. Paul Guyer and Allen W. Wood. Cambridge: Cambridge University Press, 1998.

Kant, Immanuel. Grounding for the Metaphysics of Morals, trans. James Ellington, in Kant's Ethical Philosophy, ed. Warner A. Wick. Indianapolis: Hackett Publishing Co., 1983.

Montaigne, Michel de, Michel de Montaigne: The Complete Essays, trans. and ed. M.A. Screech. London: Penguin Books, 1997.

Nietzsche, Friedrich. “Ecce Homo," in Basic Writings of Nietzsche. trans. and ed. by Walter Kaufmann. New York: Modern Library, 1967.

Parens, Joshua. Maimonides and Spinoza: Their Conflicting Views on Human Nature. Chicago: University of Chicago Press, 2012.

Rousseau, Jean-Jacques. “Letter from J.J. Rousseau to M. de Voltaire,” in Rousseau: The Discourses and Other Early Political Writings, ed. and trans. by Victor Gourevitch. Cambridge: Cambridge University Press, 1997.

Seneca, The Stoic Philosophy of Seneca, trans. Moses Hadas. New York: W. W. Norton and Company, 1958.

77 This argument follows a logic I've laid out more completely in: Dalton, The Ethics of Resistance: Tyranny of the Absolute. There I suggest that the concept of the good can only be defined negatively as that which resists every absolute and necessary position, however impractical and hopeless such a resistance may be.

78 Camus, Notebooks: 1935 - 1942, 54. 
Schopenhauer, Arthur. "On the Will in Nature," in On the Fourfold Root of the Principle of Sufficient Reason and Other Writings, trans. and ed. David E. Cartwrights, Edward E. Erdmann, and Christopher Janaway. Cambridge: Cambridge University Press, 2012

Schopenhauer, Arthur. The World as Will and Representation, vol. I, trans. E.F.J. Payne. New York: Dover Publications, 1969. Shakespeare, William. The Oxford Shakespeare: Hamlet. Oxford: Oxford University Press, 2008.

Sparrow, Tom. The End of Phenomenology: Metaphysics and the New Realism. Edinburgh: Edinburgh University Press, 2014. Spinoza, Baruch. “Letter 43,” in Complete Works. Ed. Michael L Morgan. Trans. Samuel Shirley. Indianapolis: Hackett Publishing Company, 2002.

Spinoza, Benedict. The Ethics in A Spinoza Reader: The Ethics and Other Works, ed. and trans. by Edwin Curley. Princeton: Princeton University, 1994.

Voltaire. "The Lisbon Earthquake," in The Portable Voltaire, ed. Ben Ray Redman. New York: Penguin Books, 1977. 